На кінець 1950 років було створено дискусії та конференцій 3 приводу методів навчання та навчальних програм, для поліпшення навчального процесу.

\title{
Література:
}

1. Ріглі Т. Політика навчальної програми в школах. Політичний документ Лондон: Центр трудових та соціальних досліджень. Лондон, 2014.

2. Саймон Б. Тестування інтелекту та всеосяжна школа: Лоуренс та Вішар. Лондон, 1953 рік.

3. Саймон Б. Освіта і соціальний порядок 1940-1990: Лоуренс i Вішарт. Лондон, 1991. С. 152.

4. Харві Е. Розподіл молодшої школи: Форум 2 (2) Весна. Лондон, 1960.

5. Вернон П.Е. Відбір середньої школи. Дослідження Британського психологічного товариства: Methuen \& Co Ltd. Лондон, 1957.

DOI https://doi.org/10.30525/978-9934-588-80-8-1.66

\section{BLENDED LEARNING IN THE MODERN EDUCATIONAL PROCESS TRAINING OF MEDICAL PROFESSIONALS}

\author{
Shaposhnikova V. M. \\ Candidate of Medical Sciences, Head of the Department of professional \\ medical and pharmaceutical disciplines, Cherkassy Medical Academy \\ Cherepanova M. O. \\ Head of the Department of humanities and historical disciplines \\ Cherkassy Medical Academy \\ Kravchenko O. P. \\ Candidate of Pedagogical Sciences, a teacher of the department \\ of humanities, Cherkassy Medical Academy \\ Cherkassy, Ukraine
}

The purpose of the article. The purpose of the article is to reveal the topic of blended learning and the experience of using this innovative technology at the Cherkassy Medical Academy, as well as to demonstrate a number of advantages and disadvantages of blended learning.

Theoretical basics and research methods. Blended learning is one of the modern educational technologies, which is based on the concept of 248 
combining the technologies of the place-based classroom system, with elearning and distant learning technologies. The integration of innovative technologies into the traditional educational process of the Cherkassy Medical Academy during quarantine is currently very important, which motivated us to write this article.

While writing the article the following basic research methods were used: analysis, comparison, synthesis, generalization, description.

Main research material. There are many approaches in defining blended learning, most of which are descriptive. We'll name some of them: - a combination of traditional means of training, i.e. learning in the classrooms, studying theoretical material with the informal ones, for example discussions via e-mail and Internet conferences [1, p. 25]; - a combination of different ways of delivering the educational content and educational content management system [2, p. 59]; - a combination of seemingly opposite approaches: formal and non-formal learning, face-to-face and online communication, guided actions and independent choice [3, p. 38].

At the same time, C.R. Graham notes that blended learning is an approach that integrates traditional learning and computer learning in the pedagogical environment [4, p. 225].

A Ukrainian author V. M. Kukharenko interpretes blended learning as a purposeful process of acquiring knowledge and skills in the process of integration of place-based classroom and extracurricular educational activities of the subjects in the educational process based on the use of traditional, electronic, distance and mobile learning technologies under the conditions when the student controls routes and pace personally [1, p. 201].

At the same time, K.L. Bugaychuk considers the term of «blended learning» in a narrow and broad sense. In a narrow sense, it means a purposeful process of acquiring knowledge, skills and abilities carried out by educational institutions of various types in the framework of formal education, part of this process being implemented remotely by means of information and communication technologies and teaching aids used for storage and delivery of educational material. In a broad sense, these are different options for combining forms and methods of organizing formal, non-formal, informal learning, as well as self-learning, carried out to achieve predetermined learning goals without changing the mechanism of control over time, place, routes and pace of learning [2, p. 48].

We regard blended learning is a purposeful, organized, interactive process of interaction between the students and the teachers, which didactically optimally combines the technologies of traditional and online learning based on information and communication technologies and focused on individual student's needs, regardless of location and time of learning. 
Blended and distant learning combine e-learning, and traditional learning or can include elements of e-learning.

The researchers generalized the following models of blended learning:

1. «Face-to-Face Driver» model when the main part of the curriculum is studied in the classroom in direct interaction with the teacher, and e-learning is used as a supplement to the main program.

2. In the «Rotation» model, study time is shared between individual elearning and place-based classroom learning with the teacher, who can also provide distant support during the e-learning.

3. In the «Flex» model, most of the curriculum is learned in e-learning form, and the teacher supports students remotely to work out issues that are difficult to understand, organizes classroom consultations with small groups or individually.

4. In the implementation of the "Online Lab» model the curriculum is mastered in the context of e-learning, which is organized in classrooms equipped with computer equipment, and is supported by a teacher (in combination with traditional teaching).

5. Within the framework of the «Self-blended» model, students themselves choose additional courses to basic education, conducted by various educational institutions.

6. The model «Online Driver» involves mastering most of the curriculum trough electronic resources of information and educational environment; place-based classroom training with the teacher is periodic.

The basis for the distinguishing of the presented models of blended learning is the option of correlating the traditional form of learning with elearning as well as the degree of student`s self-study, choosing sections of courses for the self-study.

Let's see how we integrate the described models into the traditional educational process of Cherkassy Medical Academy. The lecture, in addition to theoretical information, develops the interest of educational activity in general and in a chosen discipline in particular, forms guidelines for selfstudy the course. Therefore, when implementing blended learning, it is not possible to represent all the lectures into e-learning completely. We offer a rotational model «Flipped-Classroom» («Inverted learning») as a model of blended learning for the organization of lectures. It is necessary to provide two or three classroom lectures for each topic, which alternate with electronic ones. In addition, the self-blended model regarded as promising.

More flexibility in combining traditional methods with e-learning in the organization of practical classes is provided by the model of blended learning «Station Rotation», in case of each student has access to a personal computer, tablet, mobile devices. Then the teacher can dynamically switch 250 
the students from frontal to individual with online course materials, Internet services and other electronic resources. The teacher will free up time for individual counseling.

In case of Master's degree, in which the vast majority of students combine studies with work it is important to use such models of blended learning as effective one. The main emphasis here is on self e-learning with distant interaction of the teacher with the students, in addition a place-based classroom and counseling with the help of the model «Online Driver». But the effectiveness of this model depends on the quality of educational content of the electronic online course and on the mastery of distant learning technologies of the teachers.

In our opinion the pros of blended learning are: flexibility of the educational process, openness of learning, individual approach, develops the independence, increased motivation.

The material of the article allows us to make the following conclusions. The organization of the educational process based on blended learning is optimal for effective teaching. It will improve the quality of student training, the development of individual creative activity, stimulate the acquisition of additional knowledge and their consolidation, which allows to train competitive medical professionals. The model of blended learning includes the following elements: higher education strategy for the development of elearning, organization of the educational process by ICT with the support of special support services, implementation of teacher-student interaction using e-learning methods and content. Promising fields in blended learning are the study and analysis of e-learning methods, the capabilities of social networks, cloud computing, open online and offline courses and the development of methods for their use in the educational process.

\section{Literature:}

1. Kukharenko V.M. Blended learning. Webinar. [Electronic resource] / Volodymyr Mykolayovych Kukharenko. - Access mode: http://www.wiziq.com/online-class/2190095-intel-blended.

2. Bugaychuk K.L. Blended learning: theoretical analysis and strategy of implementation in the educational process of higher educational institutions / KL Bugaychuk. - Information technologies and teaching aids: electronic scientific professional publication [Electronic resource] / Inst. technologies and teaching aids of the Academy of Pedagogical Sciences of Ukraine, University of Education Management of the Academy of Pedagogical Sciences of Ukraine; head editor.: V.Yu. Bikov. - 2016. - Volume 54. № 4. - Access mode: http://journal.iitta.gov.ua/index.php/itlt/article/view/ 1434/1070. 
3. Solovov A.V. E-learning: issues, didactics, technology / A.V. Соловов. - Samara: «New technology», 2006. - 462 p.

4. Fomina A.S. Blended learning in higher educational establishments: institutional, organizational, technological and pedagogical aspects [Electronic resource] / A.S. Fomina. - Access mode: teoria-practica.ru/rus/fi les / arhiv_zhurnala /.../ fomina.pdf.

DOI https://doi.org/10.30525/978-9934-588-80-8-1.67

\title{
ШЛЯХИ ВІДРОДЖЕННЯ ТА РОЗВИТКУ ПОЛЬСЬКОЇ ПЕДАГОГІКИ КУЛЬТУРИ НАПРИКІНЦІ ХХ СТ.
}

\author{
Шостачук Т. В. \\ кандидат педагогічних наук, \\ доиент кафедри образотворчого мистеитва та дизайну \\ Житомирський державний університет імені Івана Франка \\ м. Житомир, Украӥна
}

Метою роботи $є$ дослідження шляхів відродження педагогіки культури після падіння в XX столітті тоталітарного комуністичного режиму.

У 1989 році в країнах так званого «Східного блоку» наступив тріумф демократії й незалежності, який зумовив зміни й в Республіці Польща: розпочалася комплексна трансформація у сфері політики, економіки, науки. Також відбулися значні зміни в соціальній свідомості, культурі та освіті.

У польській педагогіці культури також відбулися кардинальні зміни, які вплинули на іiі розвиток, ідентичність та статус наукової дисципліни. Мова йде про широко зрозумілу педагогічну думку, яку, за Б. Шліверським, розуміють як належність до світу гуманістики, у межах якої знаходяться предмети гуманітарних досліджень [5, с. 42-44].

Нам імпонує думка Декана Люблінської Вищої Школи (Рики) доктора К. Южиста про те, що виправданою теоретичною основою системи освіти може стати педагогіка культури як субдисципліна гуманітарних наук. Тому варто, вважає вчений, будувати теоретичні основи польської освіти на грунті досягнень, започаткованих понад століття тому [2, с. 11-32].

На його думку, педагогіка культури усупереч початим, проте малоуспішним спробам вписати іiі в процес глибоких культурних i цивілізаційних змін, які відбуваються в Республіці Польща, все ж 252 